Article

\title{
Exogenous Melatonin Reduces Lignification and Retains Quality of Green Asparagus (Asparagus officinalis L.)
}

\author{
Athip Boonsiriwit ${ }^{1,2}{ }^{\mathbb{D}}$, Myungho Lee ${ }^{1}$, Minhwi Kim ${ }^{1}$, Pontree Itkor ${ }^{1} \mathbb{D}$ and Youn Suk Lee ${ }^{1, * \mathbb{D}}$ \\ 1 Department of Packaging, Yonsei University, Wonju 220-710, Korea; athip8266@gmail.com (A.B.); \\ yb8049@naver.com (M.L.); minhwi10@gmail.com (M.K.); pontree.itkor@gmail.com (P.I.) \\ 2 Rattanakosin International College of Creative Entrepreneurship (RICE), Rajamangala University of \\ Technology Rattanakosin, Nakhon Pathom 73170, Thailand \\ * Correspondence: leeyouns@yonsei.ac.kr; Tel.: +82-33-760-2395
}

Citation: Boonsiriwit, A.; Lee, M.; Kim, M.; Itkor, P.; Lee, Y.S. Exogenous Melatonin Reduces Lignification and Retains Quality of Green Asparagus (Asparagus officinalis L.). Foods 2021, 10, 2111. https://doi.org/10.3390/ foods10092111

Academic Editor: Rinaldo Botondi

Received: 23 August 2021

Accepted: 3 September 2021

Published: 7 September 2021

Publisher's Note: MDPI stays neutral with regard to jurisdictional claims in published maps and institutional affiliations.

Copyright: (c) 2021 by the authors. Licensee MDPI, Basel, Switzerland. This article is an open access article distributed under the terms and conditions of the Creative Commons Attribution (CC BY) license (https:// creativecommons.org/licenses/by/ $4.0 /)$.

\begin{abstract}
Asparagus (Asparagus officinalis L.) is highly perishable because of its high respiration rate, which continues after harvesting and leads to weight loss, increased hardness, color change, and limited shelf life. Melatonin is an indoleamine that plays an important role in abiotic stress. This study was designed to investigate the effects of melatonin on the quality attributes of green asparagus during cold storage. Green asparagus was soaked in a melatonin solution (50, 100, and $200 \mu \mathrm{M})$ for $30 \mathrm{~min}$ and then stored at $4{ }^{\circ} \mathrm{C}$ under $90 \%$ relative humidity for 25 days. The results indicated that melatonin treatment delayed the post-harvest senescence of asparagus and maintained high chlorophyll and vitamin C levels. Melatonin treatment hindered phenylalanine ammonia-lyase and peroxidase activities and reduced lignin content, thereby delaying the increase in firmness. Moreover, melatonin treatment enhanced catalase and superoxide dismutase activities, leading to reduced hydrogen peroxide content. These results indicate that melatonin treatment can be used to maintain the post-harvest quality and prolong the shelf life of green asparagus.
\end{abstract}

Keywords: asparagus; melatonin; shelf life; lignification; post-harvest treatment

\section{Introduction}

The unique taste and texture of asparagus (Asparagus officinalis L.) have made it a popular vegetable, recognized as a rich source of nutrients and bioactive compounds with therapeutic properties, such as weight control, anti-oxidation, anticancer, radioprotection, and blood pressure control [1,2]. However, fresh asparagus has a short shelf life and a high metabolic rate and, consequently, a high post-harvest respiratory activity; this leads to weight loss, increased hardness [3,4], rapid nutrient and bioactive compound loss [4], and chlorophyll degradation [5] during storage.

The freshness of produce is one of the most important attributes that consumers consider when making purchase-related decisions. Texture is an important freshness indicator of asparagus spears and is related to their freshness. After harvesting, the firmness of asparagus increases being a general behavior of asparagus, followed by wrinkling, toughening, and hardening of the spears due to lignification [6]. Lignification is attributed to secondary cell wall formation following the upregulation of cellulose, hemicellulose, and lignin biosynthesis-related activities of enzymes such as phenylalanine ammonia-lyase (PAL) and peroxidase (POD) [6,7]. Various approaches to improving asparagus quality and extending its shelf life have been investigated, including cultivar development [8-11], agronomic management [10], post-harvest treatment [1,12-14], and improved packaging technology $[3,15]$.

Melatonin ( $N$-acetyl-5-methoxytryptamine), a natural low molecular weight indoleamine, was first reported in bovine pineal glands in 1958. The various roles of melatonin in numerous plants have been reported previously, including scavenging of free radicals and induction of biotic and abiotic stress resistance [16]. Many studies have recently reported 
that treatment of fruits and vegetables with melatonin can improve quality and shelf life. For example, melatonin treatment improved tomato quality [17], reduced decay and maintained quality in strawberries [18], delayed senescence and reduced chilling injury in peaches [16], decreased physiological deterioration of cassava [19], retarded lignification of bamboo shoots [7], delayed leaf senescence and chlorophyll degradation in Chinese flowering cabbage [20], increased the chilling tolerance of green bell pepper [21], and delayed chlorophyll degradation in broccoli, thereby extending its shelf life [22].

Asparagus is a high-value vegetable. Prolonging its freshness and shelf life by postharvest treatment may enhance its commercial potential. To the best of our knowledge, there are no available data on the effects of melatonin on post-harvest quality aspects of green asparagus spears. Therefore, the aim of the present study was to investigate the effects of melatonin on the quality attributes of green asparagus during cold storage in terms of texture; weight loss; lignin, chlorophyll, and vitamin C contents; and PAL, POD, catalase (CAT), and superoxide dismutase (SOD) activities.

\section{Materials and Methods}

\subsection{Raw Material}

Fresh green asparagus spears (A. officinalis L.) were purchased from a local farm in Wonju (Gangwon-Do, Korea) and transported to the laboratory within $2 \mathrm{~h}$, before chilling at $4{ }^{\circ} \mathrm{C}$ for $4 \mathrm{~h}$. Subsequently, they were sorted according to the following criteria: straight, undamaged, $1.2-1.5 \mathrm{~cm}$ diameter, $\sim 20 \mathrm{~cm}$ in length with closed bracts, and no visible signs of injury. The asparagus spears were randomly separated into sample sets of approximately $250 \mathrm{~g}$ each.

\subsection{Melatonin Treatment}

Melatonin $98.0 \%$ was purchased from Tokyo Chemical Industry Co., Ltd. (Tokyu, Japan). The melatonin treatment was performed at $25^{\circ} \mathrm{C}$ as described by Tan et al. [20]. Asparagus spears $(250 \mathrm{~g})$ were immersed in 50,100 , and $200 \mu \mathrm{M}$ melatonin solution (equivalent to $11.61,23.22$, and $46.44 \mathrm{mg}$ of melatonin/L of distilled water, respectively) for $30 \mathrm{~min}$, followed by air drying at $25^{\circ} \mathrm{C}$ for $45 \mathrm{~min}$; control samples were treated with distilled water. Subsequently, the samples were transferred to a perforated plastic basket and placed in an upright position for storage at $4{ }^{\circ} \mathrm{C}$ under $90 \%$ relative humidity. Sampling and analyses took place on day $0,5,10,15,20$, and 25 of storage. The 50,100 , and $200 \mu \mathrm{M}$ melatonin treatment groups are coded as: 0.5 MLT, 1.0 MLT, and 2.0 MLT, respectively.

\subsection{Quality Determination}

\subsubsection{Weight Loss}

The weight of asparagus was measured after treatment on day 0 and on the aforementioned sampling days, up to day 25. Weight loss was expressed as the percentage loss of initial weight using the following formula:

$$
\text { Weight loss }(\%)=(\text { Initial weight }- \text { final weight } / \text { Initial weight }) \times 100
$$

\subsubsection{Respiration and Ethylene Production Rate}

The respiration rate (Ri) of asparagus was measured using a closed-glass jar system. Briefly, asparagus (approximately $100 \mathrm{~g}$ ) was placed in a $1 \mathrm{~L}$ glass jar and closed with a lid attached to the septum. The packed jars were incubated in a temperature-controlled chamber at $4{ }^{\circ} \mathrm{C}$ for $1 \mathrm{~h}$. After incubation, headspace gas was measured to determine the $\mathrm{CO}_{2}$ level using a gas analyzer (PBI Dansensor-CheckMate II; Dansensor A/S, Ringsted, Denmark). Ri of asparagus was calculated using the following linear equation:

$$
R i=\left(Y_{t}-Y_{t 0}\right) \times V /(t \times M \times 100)
$$


where $\mathrm{Y}_{\mathrm{t}}$ is the $\mathrm{CO}_{2}$ gas concentration at time $\mathrm{t}, \mathrm{M}$ is the mass of the asparagus, and $\mathrm{V}$ is the volume ( $\mathrm{mL})$ of the headspace, according to Castelló et al. [23]. The results are expressed as $\mathrm{mg} \mathrm{CO} 2 / \mathrm{kg} / \mathrm{h}$.

To measure the ethylene production rate of green asparagus, the packed jars were incubated at $4{ }^{\circ} \mathrm{C}$ for $4 \mathrm{~h}$. Subsequently, $1 \mathrm{~mL}$ of the headspace gas was collected from the jar and injected into a gas chromatograph (GC; 6890 gas chromatograph, Agilent Technologies, Inc., California, USA) equipped with an internal diameter and capillary column length of $0.32 \mathrm{~mm}$ and $30 \mathrm{~m}$, respectively, and a flame ionization detector (FID). The column oven temperature was maintained at $50{ }^{\circ} \mathrm{C}$ for $3 \mathrm{~min}$ and then increased to $250{ }^{\circ} \mathrm{C}$ at a rate of $15^{\circ} \mathrm{C} / \mathrm{min}$. The injector and FID temperatures were 100 and $250^{\circ} \mathrm{C}$, respectively. Helium was used as the carrier gas at a flow rate of $10 \mathrm{~mL} / \mathrm{min}$. The identified peak was compared with the standard curve and the retention time. The amount of ethylene gas in the headspace was calculated and expressed as $\mu \mathrm{LC}_{2} \mathrm{H}_{4} / \mathrm{kg} / \mathrm{h}$.

\subsubsection{Texture Analysis}

The asparagus spears, $20 \mathrm{~cm}$ in length, were marked at the following three points: apical ( $3 \mathrm{~cm}$ from the tip), middle (middle of the spear), and basal $(3 \mathrm{~cm}$ from the base). The texture was analyzed at the marked point of each of the three sections of each spear by applying the cutting test using a TA1 Texture Analyzer (Lloyd Instruments / Ametek, Largo, FL, USA) with a $1 \mathrm{~mm}$ diameter shear blade and a constant moving rate of $5 \mathrm{~mm} / \mathrm{s}$ for a $5 \mathrm{~mm}$ cutting depth [3]. The maximum force $(\mathrm{N})$ was expressed as the mean of 10 replicates.

\subsubsection{Objective Color Measurement}

The external color attributes of asparagus were measured using a colorimeter (Konica Minolta Sensing, Inc., Osaka, Japan) equipped with an $8 \mathrm{~mm}$ measuring head and a C illuminant $(6774 \mathrm{~K})$ to obtain $L^{*}, a^{*}$, and $b^{*}$ values. The device was calibrated using a standard white plate. Measurements were taken in the middle of the sample $(n=10$ asparagus spears/treatment). The following equation was used to calculate the total color difference $(\Delta E)$ :

$$
\Delta E=\sqrt{\left(L^{*}-L_{0}^{*}\right)^{2}+\left(a^{*}-a_{0}^{*}\right)^{2}+\left(b^{*}-b_{0}^{*}\right)^{2}}
$$

where $L_{0}{ }^{*}, a_{0}{ }^{*}$, and $b_{0}{ }^{*}$ are the initial color parameters measured on day 0 and $L^{*}, a^{*}$, and $b^{*}$ are the color values of asparagus measured at different storage periods.

\subsubsection{Chlorophyll Content}

Asparagus (50 g) was chopped, and $1.0 \mathrm{~g}$ of the chopped tissue was homogenized at a moderate speed for $30 \mathrm{~s}$ in $20 \mathrm{~mL}$ of $80 \%$ acetone. After homogenization, $80 \%$ acetone solution was used to wash the paste into a $50 \mathrm{~mL}$ volumetric flask and then made up to volume with $80 \%$ acetone. The homogenate was filtered through two layers of filter paper and centrifuged at $10,000 \times \mathrm{g}$ for $15 \mathrm{~min}$ at $4{ }^{\circ} \mathrm{C}$. The absorbance was read at $647\left(\mathrm{Abs}_{647}\right)$ and $664.5 \mathrm{~nm}\left(\mathrm{Abs}_{664.5}\right)$ using a UV-vis spectrophotometer (V-650 Spectrophotometer; JASCO Corporation, Tokyo, Japan). The total chlorophyll content, expressed on a fresh weight (FW) basis, was calculated as follows [5]:

$$
\text { Chlorophyll content }(\mathrm{mg} / \mathrm{Kg} \mathrm{FW})=5 \times\left[17.95 \times \mathrm{Abs}_{647}+8.08 \times \mathrm{Abs}_{664.5}\right]
$$

\subsubsection{Vitamin C Content}

The vitamin C (ascorbic acid) content of asparagus, expressed as mg/100 $\mathrm{g}$ FW, was determined using the method of the Association of Official Analytical Chemists [24]. Briefly, a $5 \mathrm{~g}$ sample of $50 \mathrm{~g}$ of chopped asparagus was blended with $50 \mathrm{~mL}$ of metaphosphoricacetic acid solution to extract ascorbic acid. The mixture was homogenized at $12,000 \times g$ (on ice, shielded from light) for $1 \mathrm{~min}$ and then centrifuged at $9000 \times \mathrm{g}$ for $20 \mathrm{~min}$ at $4{ }^{\circ} \mathrm{C}$. The supernatant was transferred to a volumetric flask and rapidly titrated with indophenol solution until a distinct rose-pink color persisted for more than $5 \mathrm{~s}$. 


\subsubsection{Lignin Content}

The lignin content was determined using the method described by Fukushima et al. [25]. Briefly, fresh asparagus tissue $(1.0 \mathrm{~g})$ was homogenized with $5 \mathrm{~mL}$ of $95 \%$ ethanol $(v / v)$ using an Ultra-Turrax homogenizer (IKA, Staufen, Germany) and centrifuged at 10,000 $\mathrm{g}$ for $10 \mathrm{~min}$ at $4{ }^{\circ} \mathrm{C}$ (2236R; Labogene, Daejeon, Korea). The residue was washed three times with $3 \mathrm{~mL}$ of ethanol:hexane $(1: 2, v / v)$ solution. Then, the sample was dissolved in $1 \mathrm{~mL}$ of acetyl bromide:acetic acid $(1: 3, v / v)$ solution and allowed to digest in a $50{ }^{\circ} \mathrm{C}$ water bath for $2 \mathrm{~h}$ with shaking every $30 \mathrm{~min}$. After cooling and centrifugation $(3000 \times g$ for $15 \mathrm{~min})$, the digested solution $(0.5 \mathrm{~mL})$ was added to a tube containing $6.5 \mathrm{~mL}$ of acetic acid and $2.0 \mathrm{~mL}$ of $0.3 \mathrm{M} \mathrm{NaOH}$. The contents were mixed, and hydroxylamine hydrochloride solution $(1.0 \mathrm{~mL})$ was added, followed by additional mixing of the contents, after which the absorbance of the samples at $280 \mathrm{~nm}$ was measured. The lignin content was calculated by comparing with a standard coumaric acid curve and expressed as $\mathrm{g} / \mathrm{Kg}$ FW of asparagus.

\subsubsection{Hydrogen Peroxide $\left(\mathrm{H}_{2} \mathrm{O}_{2}\right)$ Content}

The concentration of $\mathrm{H}_{2} \mathrm{O}_{2}$ was measured colorimetrically, according to Jana et al. [26]. Briefly, $5 \mathrm{~g}$ of the sample was homogenized with $50 \mathrm{~mL}$ of phosphate buffer $(50 \mathrm{mM}$, $\mathrm{pH}$ 6.5). Subsequently, the homogenate was centrifuged at $10,000 \times \mathrm{g}$ for $30 \mathrm{~min}$ at $4{ }^{\circ} \mathrm{C}$. Three milliliters of the supernatant was mixed with $1 \mathrm{~mL}$ of $0.1 \%$ titanium sulfate in $20 \%$ $(v / v) \mathrm{H}_{2} \mathrm{SO}_{4}$. The absorbance of the sample at $480 \mathrm{~nm}$ was recorded. The $\mathrm{H}_{2} \mathrm{O}_{2}$ content was calculated by comparing with a standard $\mathrm{H}_{2} \mathrm{O}_{2}$ curve and expressed as mg/100 g FW of asparagus.

\subsubsection{Enzyme Activity Assays}

PAL activity was measured as described by Wang et al. [27]. Briefly, fresh asparagus tissue samples $(2.0 \mathrm{~g})$ were ground with $6 \mathrm{~mL}$ of $50 \mathrm{mM}$ Tris- $\mathrm{HCl}$ buffer $(\mathrm{pH} 8.8)$ containing $15 \mathrm{mM} \beta$-mercaptoethanol, $5 \mathrm{mM}$ ethylenediaminetetraacetic acid (EDTA), $5 \mathrm{mM}$ ascorbic acid, and $0.15 \%(w / v)$ polyvinylpyrrolidone (PVP). The homogenate was centrifuged at $12,000 \times g$ for $30 \mathrm{~min}$ at $4{ }^{\circ} \mathrm{C}$. The supernatant was used as a source of crude enzyme to assay PAL activity. The reaction mixture $(3 \mathrm{~mL})$, containing $16 \mathrm{mM} \mathrm{L}$-phenylalanine, $50 \mathrm{mM}$ Tris- $\mathrm{HCl}$ buffer ( $\mathrm{pH} 8.9), 3.6 \mathrm{mM} \mathrm{NaCl}$, and crude enzyme extract $(0.5 \mathrm{~mL})$, was incubated at $37^{\circ} \mathrm{C}$ for $1 \mathrm{~h}$; the reaction was stopped by adding $500 \mu \mathrm{L}$ of $6 \mathrm{M} \mathrm{HCl}$. PAL activity, expressed as $\mathrm{U} / \mathrm{mg}$ protein, was determined by monitoring the increase in absorbance at $290 \mathrm{~nm}$.

POD activity was measured according to the method described by Zhang et al. [28]. Two grams of the sample was homogenized with $10 \mathrm{~mL}$ of $0.05 \mathrm{mM}$ sodium phosphate buffer ( $\mathrm{pH} 7.0)$ containing PVP $(0.2 \mathrm{~g})$. The homogenate was then centrifuged at $12,000 \times \mathrm{g}$ for $30 \mathrm{~min}$ at $4{ }^{\circ} \mathrm{C}$; the supernatant was collected as the crude enzyme extract. The POD reaction mixture contained $1 \mathrm{~mL}$ of guaiacol, $0.25 \mathrm{~mL}$ of enzyme extract, and $1.75 \mathrm{~mL}$ of phosphate buffer ( $\mathrm{pH}$ 7.0). POD activity, expressed as $\mathrm{U} / \mathrm{mg}$ protein, was determined by monitoring the increase in absorbance at $470 \mathrm{~nm}$.

CAT activity, expressed as $\mathrm{U} / \mathrm{mg}$ protein, was measured using the method described by Li et al. [29] with some modifications. Briefly, $2 \mathrm{~g}$ of sample was homogenized with $10 \mathrm{~mL}$ of $0.2 \mathrm{M}$ phosphate buffer (pH 7.8) containing 1\% $(w / v)$ PVP and then centrifuged at $12,000 \times \mathrm{g}$ for $30 \mathrm{~min}$ at $4{ }^{\circ} \mathrm{C}$; the supernatant was collected as the crude enzyme extract. The CAT reaction contained $0.2 \mathrm{~mL}$ of crude enzyme, $0.3 \mathrm{~mL}$ of $0.1 \mathrm{M} \mathrm{H}_{2} \mathrm{O}_{2}, 1.5 \mathrm{~mL}$ of phosphate buffer ( $\mathrm{pH} \mathrm{7)}$, and $1 \mathrm{~mL}$ of distilled water. CAT activity was determined by monitoring the decline in absorbance at $240 \mathrm{~nm}$, reflecting the decrease in $\mathrm{H}_{2} \mathrm{O}_{2}$ content.

SOD extraction was performed using the method described by Li et al. [29]. Two grams of fresh asparagus tissue was homogenized with $10 \mathrm{~mL}$ of $50 \mathrm{mM}$ phosphate buffer, containing $0.1 \mathrm{mM}$ EDTA, $0.3 \%(w / v)$ TritonX-100, and $4 \%(w / v)$ PVP. The homogenate was then centrifuged at $12,000 \times \mathrm{g}$ for $30 \mathrm{~min}$ at $4{ }^{\circ} \mathrm{C}$; the supernatant was collected as the crude enzyme extract. SOD activity was measured according to Tang et al. [30] and expressed as $\mathrm{U} / \mathrm{mg}$ protein. 


\subsection{Statistical Analysis}

Statistical analysis was performed using IBM SPSS Statistics for Windows (Version 24.0.; IBM, Armonk, NY, USA). Firmness and color analyses were conducted in 10 replicates, whereas the other analyses were conducted in triplicate. Duncan's multiple range test was used to determine significant differences at $p<0.05$. Different superscript lowercase letters are used for comparing significant differences in the same column while different superscript uppercase letters are used for comparing significant differences in the same row $(p<0.05)$. Data are displayed as the mean \pm standard deviation.

\section{Results and Discussion}

Asparagus quality changes rapidly after harvesting because of the high Ri. Typically, asparagus spears have a shelf life of 3-5 days under ambient temperature storage. Post-harvest physiological, chemical, and biological compositional changes that reduce asparagus quality include bract opening, toughening, weight loss, chlorophyll degradation, and vitamin $\mathrm{C}$ loss.

\subsection{Effect of Melatonin Treatment on Weight Loss, Respiration, and Ethylene Production Rate}

Water transpiration has a critical effect on several physiological reactions in asparagus. Moreover, asparagus water loss is also crucial in terms of marketing; weight loss $<6 \%$ during asparagus spear storage is considered acceptable [31]. Asparagus weight loss is primarily attributed to differences in the water vapor pressure between the spear surface and the atmosphere. Herein, the weight loss of asparagus in all treatment groups increased gradually during storage (Figure 1a). All the melatonin-treated asparagus spears presented with significantly decreased weight loss compared with the control from day 15 until the end of the storage period. The weight loss of the control group after 20 days $(6.18 \pm 0.61 \%)$ exceeded the rejection limit (i.e., weight loss $>6 \%$ ), whereas 0.5 MLT and 2.0 MLT exceeded the rejection limit after 25 days. Notably, 1.0 MLT did not exceed the weight loss limit during the entire storage period. At the end of the storage period, the control group weight loss amounted to $9.06 \pm 0.41 \%$ whereas that of 0.5 MLT, 1.0 MLT, and 2.0 MLT amounted to $6.83 \pm 0.59,5.66 \pm 0.19$, and $6.01 \pm 0.49 \%$, respectively. These results indicate that melatonin treatment delays water loss by 5 days. Treatment with $1.0 \mathrm{mM}$ melatonin showed the best results because the weight loss was still within the acceptable range at the end of the storage period.

Respiration of fresh produce is related to product deterioration, nutrient loss, and short shelf life [32]. In this study, the initial Ri (Figure 1b) of all treatment groups was the same, i.e., in the range of $16.34-17.53 \mathrm{mg} \mathrm{CO}_{2} / \mathrm{kg} / \mathrm{h}$. During storage, Ri showed the same pattern in all groups, increasing gradually until day 20 before subsequently decreasing. 0.5 MLT displayed significantly lower Ri than the control after 15 days of storage, whereas Ri of 1.0 MLT and 2.0 MLT was significantly lower than that of the control from day 5. At the end of storage (day 25), the control group Ri was $29.42 \pm 1.93 \mathrm{mg} \mathrm{CO} / \mathrm{kg} / \mathrm{h}$ whereas that of 0.5 MLT, 1.0 MLT, and 2.0 MLT was $22.89 \pm 2.20,18.19 \pm 1.30$, and $20.95 \pm 1.43 \mathrm{mg}$ $\mathrm{CO}_{2} / \mathrm{kg} / \mathrm{h}$, respectively. The lower Ri of melatonin-treated asparagus may be attributed to attenuation of the Embden-Meyerhof-Parnas pathway, which is related to the generation of ATP and NADH during glucose metabolism, resulting in a reduced Ri [33,34]. Similar results have been reported for Chinese flowering cabbage [33], apples [35], cherries [36], and mushrooms [37].

The ethylene production rate increased in all treatment groups with increasing storage periods (Figure 1c). On day 0, there were no significant differences observed between the ethylene production rate of the control and that of the melatonin-treated asparagus (value range $=0.11-0.14 \mu \mathrm{L} / \mathrm{kg} / \mathrm{h}$ ). However, the ethylene production rate of all melatonin treatment groups was significantly lower than that of the control group from day 5 . The ethylene production rate of 0.5 MLT, 1.0 MLT, and 2.0 MLT was 17.14, 30.58, and $29.65 \%$ lower than that of the control group, respectively, at the end of the storage period. The lower ethylene production rate of melatonin-treated asparagus may be the result 
of downregulation of the expression of ethylene biosynthesis-related genes [38]. This finding is consistent with reports that melatonin treatment inhibited ethylene production in bananas [39]. Excessive ethylene synthesis leads to the deterioration of vegetables, thereby increasing hydrolytic enzyme activity, which reduces the nutrient and chlorophyll content $[5,40,41]$.
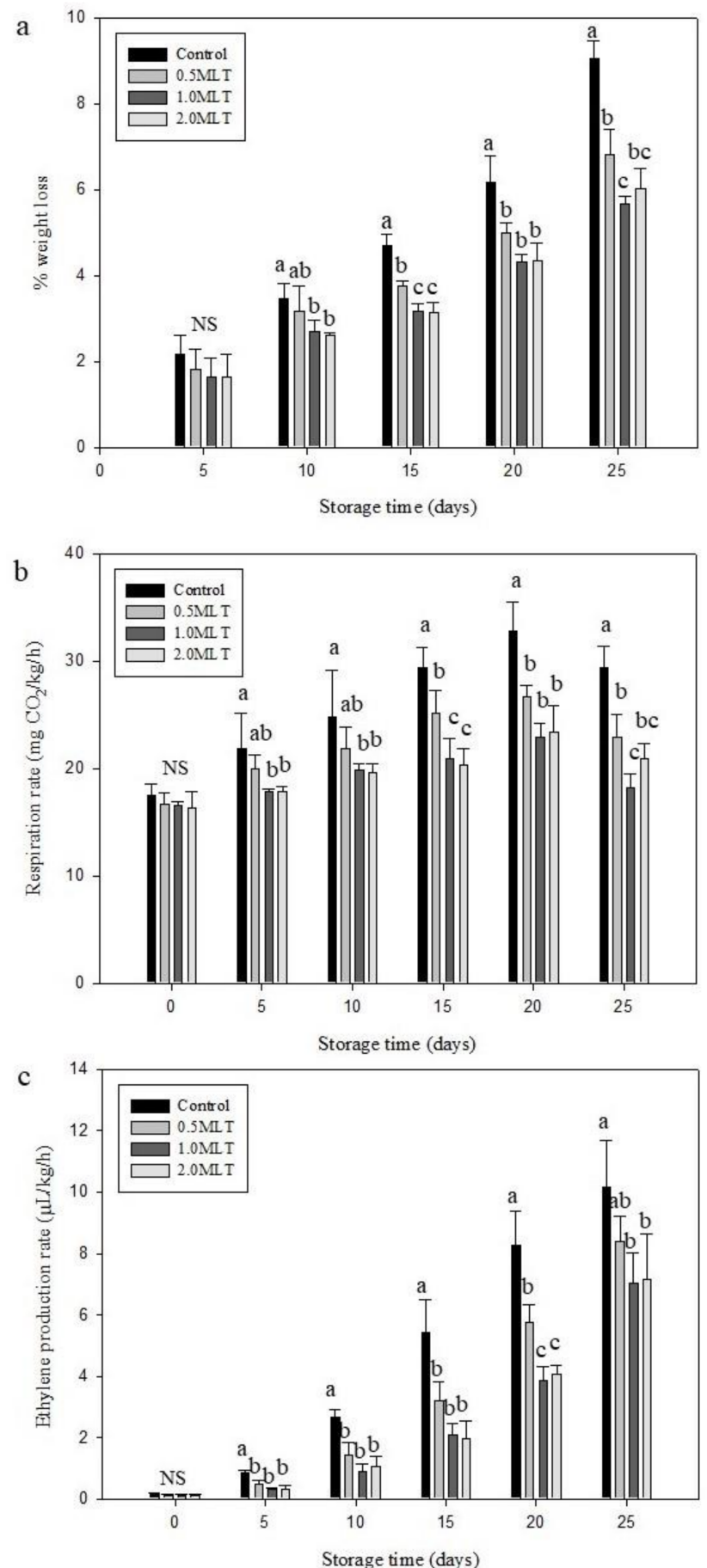

Figure 1. Effect of melatonin treatment on the percentage weight loss (a), respiration rate (b), and ethylene production rate (c) of green asparagus during 25 days of storage at $4{ }^{\circ} \mathrm{C}$ and $90 \%$ relative humidity. Treatment in melatonin solution: 0.5 MLT $(50 \mu \mathrm{M}), 1.0$ MLT $(100 \mu \mathrm{M})$, 2.0 MLT $(200 \mu \mathrm{M})$; control (distilled water). Values are presented as mean \pm standard deviation $(n=3)$. Different letters indicate significant differences $(p<0.05)$; NS = not significant. 


\subsection{Effect of Melatonin Treatment on Texture}

Texture is one of the criteria used for quality assurance and the assessment of asparagus quality deterioration. The firmness differs depending on the site of analysis; the apical part is less firm than the basal part [12]. Strength and toughness are related to fibrousness and the hardening process that occurs after harvesting; the latter is accompanied by lignification of pericyclic (sclerenchyma) fibers. Furthermore, these characteristics may also be associated with respiratory water loss and increases in phenolic compounds, besides lignin [3]. The firmness values for both the melatonin-treated and control samples, measured at the apical and middle parts of asparagus, were in the range of $29.08-34.61 \mathrm{~N}$ (Table 1) and did not show significant differences among the sampling days. However, the firmness in the basal part of the control samples increased over the storage period, from $35.16 \pm 4.13$ to $52.20 \pm 4.22 \mathrm{~N}$. The basal firmness of $0.5 \mathrm{MLT}$ was significantly lower than that of the control at day 10 of storage; however, the increase in firmness was significantly delayed from day 5 in 1.0 MLT and 2.0 MLT, with day 25 measurements of $40.19 \pm 7.55$ and $40.71 \pm 4.37 \mathrm{~N}$, respectively, i.e., 23.00 and $22.01 \%$ lower than the control value, respectively.

Table 1. Effect of melatonin treatment on firmness $(\mathrm{N})$ at the apical, middle, and basal parts of green asparagus during 25 days of storage at $4{ }^{\circ} \mathrm{C}$ and $90 \%$ relative humidity.

\begin{tabular}{|c|c|c|c|c|c|c|c|}
\hline \multirow{2}{*}{$\begin{array}{c}\text { Part of } \\
\text { Asparagus }\end{array}$} & \multirow{2}{*}{ Treatment } & \multicolumn{6}{|c|}{ Storage Time (Days) } \\
\hline & & 0 & 5 & 10 & 15 & 20 & 25 \\
\hline \multirow{4}{*}{ Apical } & & $31.21 \pm 3.03^{\mathrm{a}, \mathrm{A}}$ & $30.80 \pm 3.84^{\mathrm{a}, \mathrm{A}}$ & $33.07 \pm 3.07^{\mathrm{a}, \mathrm{A}}$ & $30.24 \pm 2.47^{\mathrm{a}, \mathrm{A}}$ & $34.61 \pm 6.39^{\mathrm{a}, \mathrm{A}}$ & $33.51 \pm 7.28^{\mathrm{a}, \mathrm{A}}$ \\
\hline & $0.5 \mathrm{MLT}$ & $31.56 \pm 2.43^{\mathrm{a}, \mathrm{A}}$ & $32.28 \pm 2.31^{\mathrm{a}, \mathrm{A}}$ & $30.17 \pm 4.48^{\mathrm{a}, \mathrm{A}}$ & $31.73 \pm 3.39^{\mathrm{a}, \mathrm{A}}$ & $33.27 \pm 5.02^{\mathrm{a}, \mathrm{A}}$ & $33.43 \pm 4.31^{\mathrm{a}, \mathrm{A}}$ \\
\hline & 1.0 MLT & $31.39 \pm 2.95^{\mathrm{a}, \mathrm{A}}$ & $30.22 \pm 4.12 \mathrm{a}, \mathrm{A}$ & $32.52 \pm 3.49^{\mathrm{a}, \mathrm{A}}$ & $30.06 \pm 4.21^{\mathrm{a}, \mathrm{A}}$ & $34.42 \pm 6.23 \mathrm{a}, \mathrm{A}$ & $33.92 \pm 3.65^{\mathrm{a}, \mathrm{A}}$ \\
\hline & $2.0 \mathrm{MLT}$ & $30.32 \pm 3.13^{\mathrm{a}, \mathrm{A}}$ & $33.41 \pm 2.00^{\mathrm{a}, \mathrm{A}}$ & $32.09 \pm 4.17^{\mathrm{a}, \mathrm{A}}$ & $31.49 \pm 3.95^{\mathrm{a}, \mathrm{A}}$ & $33.95 \pm 4.50^{\mathrm{a}, \mathrm{A}}$ & $34.52 \pm 3.84^{\mathrm{a}, \mathrm{A}}$ \\
\hline \multirow{4}{*}{ Middle } & Control & $31.90 \pm 3.13^{\mathrm{a}, \mathrm{A}}$ & $29.32 \pm 3.67^{\mathrm{a}, \mathrm{A}}$ & $34.17 \pm 3.37^{\mathrm{a}, \mathrm{A}}$ & $33.42 \pm 3.16^{\mathrm{a}, \mathrm{A}}$ & $33.52 \pm 4.67^{\mathrm{a}, \mathrm{A}}$ & $29.55 \pm 2.30^{\mathrm{a}, \mathrm{A}}$ \\
\hline & $0.5 \mathrm{MLT}$ & $32.40 \pm 2.71^{\mathrm{a}, \mathrm{A}}$ & $29.08 \pm 4.59 \mathrm{a}, \mathrm{A}$ & $30.08 \pm 4.65^{\mathrm{a}, \mathrm{A}}$ & $30.56 \pm 4.11^{\mathrm{a}, \mathrm{A}}$ & $31.41 \pm 6.13^{\mathrm{a}, \mathrm{A}}$ & $29.81 \pm 2.05^{\mathrm{a}, \mathrm{A}}$ \\
\hline & 1.0 MLT & $32.50 \pm 3.81^{\mathrm{a}, \mathrm{A}}$ & $30.02 \pm 4.44^{\mathrm{a}, \mathrm{A}}$ & $30.33 \pm 4.70^{\mathrm{a}, \mathrm{A}}$ & $31.44 \pm 4.58^{\mathrm{a}, \mathrm{A}}$ & $31.30 \pm 3.96^{\mathrm{a}, \mathrm{A}}$ & $30.31 \pm 4.71^{\mathrm{a}, \mathrm{A}}$ \\
\hline & $2.0 \mathrm{MLT}$ & $31.20 \pm 3.06^{\mathrm{a}, \mathrm{A}}$ & $31.55 \pm 6.83^{\mathrm{a}, \mathrm{A}}$ & $31.38 \pm 3.21^{\mathrm{a}, \mathrm{A}}$ & $32.55 \pm 6.29^{a, A}$ & $32.41 \pm 4.48^{\mathrm{a}, \mathrm{A}}$ & $29.65 \pm 4.29^{\mathrm{a}, \mathrm{A}}$ \\
\hline \multirow{4}{*}{ Basal } & ntrol & $35.46 \pm 4.13^{\mathrm{a}, \mathrm{A}}$ & $41.36 \pm 5.35^{\mathrm{c}, \mathrm{B}}$ & $46.82 \pm 5.96^{c, C}$ & $48.66 \pm 6.40^{\mathrm{b}, \mathrm{D}}$ & $50.06 \pm 2.16^{\mathrm{c}, \mathrm{E}}$ & $52.20 \pm 4.22^{\mathrm{c}, \mathrm{F}}$ \\
\hline & 0.5 MLT & $36.37 \pm 2.03^{\mathrm{a}, \mathrm{A}}$ & $38.35 \pm 4.14^{\mathrm{bc}, \mathrm{A}}$ & $40.54 \pm 4.34^{\mathrm{b}, \mathrm{B}}$ & $43.76 \pm 8.89^{a b, C}$ & $45.38 \pm 4.05^{\mathrm{b}, \mathrm{D}}$ & $46.50 \pm 5.28^{\mathrm{b}, \mathrm{D}}$ \\
\hline & 1.0 MLT & $35.49 \pm 3.45^{\mathrm{a}, \mathrm{A}}$ & $34.88 \pm 5.33^{\mathrm{ab}, \mathrm{A}}$ & $35.74 \pm 6.09^{\mathrm{a}, \mathrm{A}}$ & $37.73 \pm 3.72^{\mathrm{a}, \mathrm{B}}$ & $39.37 \pm 3.66^{a, C}$ & $40.19 \pm 7.55^{\mathrm{a}, \mathrm{C}}$ \\
\hline & 2.0 MLT & $35.16 \pm 4.81^{\mathrm{a}, \mathrm{A}}$ & $34.16 \pm 4.96^{\mathrm{a}, \mathrm{A}}$ & $35.36 \pm 4.19^{\mathrm{a}, \mathrm{A}}$ & $38.40 \pm 5.15^{\mathrm{a}, \mathrm{B}}$ & $39.56 \pm 4.48^{\mathrm{a}, \mathrm{C}}$ & $40.71 \pm 4.37^{\mathrm{a}, \mathrm{C}}$ \\
\hline
\end{tabular}

Treatment in melatonin solution: 0.5 MLT $(50 \mu \mathrm{M})$, 1.0 MLT $(100 \mu \mathrm{M}), 2.0$ MLT $(200 \mu \mathrm{M})$; control (distilled water). Firmness values (N) are presented as mean \pm standard deviation $(n=10)$. Different superscript lowercase letters in the same column of each part of asparagus indicate significant differences $(p<0.05)$; Different superscript uppercase letters in the same row indicate significant differences $(p<0.05)$.

\subsection{Effect of Melatonin Treatment on Color and Chlorophyll Content}

Color has a critical effect on consumer acceptability. Therefore, objective color measurements $\left(L^{*}, a^{*}\right.$, and $\left.b^{*}\right)$ were taken to monitor the quality of green asparagus during the storage period (Table 2). The initial $L^{*}$ values of all the treatment groups were approximately 57 . The $L^{*}$ value of the control decreased gradually until the end of storage, with a value of $48.05 \pm 2.65$ at day 25 . Melatonin treatment significantly delayed the decrease in $L^{*} ; 0.5$ MLT had relatively high $L^{*}$ values $(>57)$ for up to day 10 , after which it decreased to $51.95 \pm 2.64$ by day 25 , whereas 1.0 MLT and 2.0 MLT maintained $L^{*}$ values $>57$ for 15 days, followed by gradual decreases to $53.60 \pm 1.67$ and $53.23 \pm 2.36$, respectively, by day 25 . At the end of the storage period, the $L^{*}$ value of 0.5 MLT, 1.0 MLT, and 2.0 MLT was 8.11, 11.55, and $10.78 \%$ higher than that of the control group, respectively. These results indicate that melatonin treatment can delay the decrease in the lightness color attribute of asparagus spears during cold storage. 
Table 2. Effect of melatonin treatment on color attributes $\left(L^{*}, a^{*}, b^{*}\right)$ of green asparagus during 25 days of storage at $4{ }^{\circ} \mathrm{C}$ and $90 \%$ relative humidity.

\begin{tabular}{|c|c|c|c|c|c|c|c|}
\hline \multirow{2}{*}{$\begin{array}{c}\text { Color } \\
\text { Parameter }\end{array}$} & \multirow{2}{*}{ Treatment } & \multicolumn{6}{|c|}{ Storage Time (Days) } \\
\hline & & 0 & 5 & 10 & 15 & 20 & 25 \\
\hline \multirow{4}{*}{$L^{*}$} & Control & $57.30 \pm 1.60^{\mathrm{a}, \mathrm{A}}$ & $54.56 \pm 3.32^{\mathrm{a}, \mathrm{B}}$ & $53.42 \pm 1.52^{a, B}$ & $52.94 \pm 2.09^{\mathrm{a}, \mathrm{B}}$ & $49.28 \pm 2.20^{\mathrm{a}, \mathrm{C}}$ & $48.05 \pm 2.65^{\mathrm{a}, \mathrm{C}}$ \\
\hline & 0.5 MLT & $57.35 \pm 1.87^{\mathrm{a}, \mathrm{AB}}$ & $58.89 \pm 2.15^{\mathrm{b}, \mathrm{A}}$ & $57.31 \pm 1.67^{\mathrm{b}, \mathrm{AB}}$ & $55.59 \pm 1.10^{\mathrm{a}, \mathrm{B}}$ & $52.99 \pm 1.34^{\mathrm{b}, \mathrm{C}}$ & $51.95 \pm 2.64^{b, C}$ \\
\hline & $1.0 \mathrm{MLT}$ & $57.82 \pm 1.60^{\mathrm{a}, \mathrm{A}}$ & $58.19 \pm 3.38^{\mathrm{b}, \mathrm{A}}$ & $58.87 \pm 2.25^{\mathrm{b}, \mathrm{A}}$ & $57.46 \pm 2.18^{\mathrm{c}, \mathrm{A}}$ & $54.81 \pm 2.62 \mathrm{bc,B}$ & $53.60 \pm 1.67^{b, B}$ \\
\hline & $2.0 \mathrm{MLT}$ & $57.52 \pm 1.24 \mathrm{a}, \mathrm{AB}$ & $58.99 \pm 3.31^{\mathrm{b}, \mathrm{A}}$ & $58.78 \pm 2.36^{\mathrm{b}, \mathrm{A}}$ & $57.02 \pm 1.96^{\mathrm{bc}, \mathrm{AB}}$ & $55.27 \pm 2.93^{\mathrm{c}, \mathrm{BC}}$ & $53.23 \pm 2.36^{b, C}$ \\
\hline \multirow{4}{*}{$a^{*}$} & Control & $-6.93 \pm 0.59^{\mathrm{a}, \mathrm{A}}$ & $-6.11 \pm 1.36^{\mathrm{a}, \mathrm{B}}$ & $-5.77 \pm 0.93^{\mathrm{a}, \mathrm{BC}}$ & $-5.68 \pm 0.42^{\mathrm{a}, \mathrm{BC}}$ & $-5.35 \pm 0.70^{\mathrm{a}, \mathrm{BC}}$ & $-5.31 \pm 0.94^{\mathrm{a}, \mathrm{C}}$ \\
\hline & $0.5 \mathrm{I}$ & $-6.99 \pm 0.57^{\mathrm{a}, \mathrm{A}}$ & $-6.58 \pm 0.83^{\mathrm{a}, \mathrm{AB}}$ & $\pm 0.58^{\mathrm{b}, \mathrm{AB}}$ & $-6.20 \pm 0.81^{b, B C}$ & & $-5.58 \pm 0.80^{b, C}$ \\
\hline & $1.0 \mathrm{MLT}$ & $-6.98 \pm 0.52^{\mathrm{a}, \mathrm{A}}$ & $-6.75 \pm 0.40^{\mathrm{a}, \mathrm{AB}}$ & $\pm 0.94 \mathrm{~b}, \mathrm{AB}$ & $-6.49 \pm 0.80^{\mathrm{b}, \mathrm{ABC}}$ & $\mathrm{b}, \mathrm{BC}$ & $-5.99 \pm 0.30^{b, C}$ \\
\hline & $2.0 \mathrm{MLT}$ & $-6.93 \pm 0.40^{\mathrm{a}, \mathrm{A}}$ & $-6.93 \pm 0.40^{\mathrm{a}, \mathrm{A}}$ & $-6.60 \pm 1.06^{b, A B}$ & $-6.31 \pm 0.3$ & & $-5.54 \pm 0.47^{\mathrm{b}, \mathrm{D}}$ \\
\hline \multirow{4}{*}{$b^{*}$} & Control & $32.09 \pm 1.45^{\mathrm{a}, \mathrm{A}}$ & $33.98 \pm 3.06^{\mathrm{a}, \mathrm{AB}}$ & $34.17 \pm 1.42^{\mathrm{a}, \mathrm{AB}}$ & $35.74 \pm 2.90^{\mathrm{b}, \mathrm{BC}}$ & $36.45 \pm 2.42^{b, C}$ & $37.67 \pm 2.31^{b, C}$ \\
\hline & $0.5 \mathrm{MLT}$ & $32.19 \pm 1.38^{\mathrm{a}, \mathrm{A}}$ & $32.67 \pm 2.95^{\mathrm{a}, \mathrm{AB}}$ & $33.94 \pm 2.18^{\mathrm{a}, \mathrm{AB}}$ & $34.21 \pm 1.47^{\mathrm{ab}, \mathrm{BC}}$ & $34.63 \pm 1.11^{\mathrm{a}, \mathrm{C}}$ & $35.26 \pm 2.24^{\mathrm{a}, \mathrm{C}}$ \\
\hline & 1.0 MLT & $31.62 \pm 1.24^{\mathrm{a}, \mathrm{A}}$ & $32.08 \pm 1.59^{\mathrm{a}, \mathrm{A}}$ & $33.38 \pm 1.85^{\mathrm{a}, \mathrm{AB}}$ & $33.65 \pm 2.03^{\mathrm{a}, \mathrm{AB}}$ & $33.84 \pm 1.77^{\mathrm{a}, \mathrm{B}}$ & $34.84 \pm 2.12^{\mathrm{a}, \mathrm{B}}$ \\
\hline & 2.0 MLT & $32.14 \pm 1.44^{\mathrm{a}, \mathrm{A}}$ & $33.27 \pm 2.12^{\mathrm{a}, \mathrm{AB}}$ & $33.55 \pm 2.54^{\mathrm{a}, \mathrm{AB}}$ & $34.12 \pm 1.94^{\mathrm{ab}, \mathrm{AB}}$ & $34.27 \pm 1.99 \mathrm{a}, \mathrm{AB}$ & $34.98 \pm 3.33^{\mathrm{a}, \mathrm{B}}$ \\
\hline
\end{tabular}

Treatment in melatonin solution: 0.5 MLT (50 $\mu \mathrm{M}), 1.0 \mathrm{MLT}(100 \mu \mathrm{M}), 2.0 \mathrm{MLT}(200 \mu \mathrm{M})$; control (distilled water). Values are presented as mean \pm standard deviation $(n=10)$. Different superscript lowercase letters in the same column indicate significant differences $(p<0.05)$; Different superscript uppercase letters in the same row indicate significant differences $(p<0.05)$.

The $a^{*}$ value relates to the green-red opponent color axis, with negative values ascribed to green and positive values ascribed to red. Therefore, a loss of the green color of asparagus is associated with an increase in $a^{*}$. The initial $a^{*}$ value of all samples ranged between -6.98 and -6.93 . There was no significant difference between the $a^{*}$ values of the control and melatonin treatment groups at day 5 of storage. However, the $a^{*}$ value of all melatonin treatment groups was significantly lower than that of the control from day 10 until the end of storage, indicating that melatonin treatment delays the loss of green color.

The yellowness ( $b^{*}$ value) of all treatment groups increased with time. There was no significant difference between the $b^{*}$ value of the control and melatonin treatment during storage for the first 10 days. However, the $b^{*}$ value of 1.0 MLT was significantly lower than that of the control at day 15; 0.5 MLT and 2.0 MLT had a significantly lower $b^{*}$ value than the control at day 20 . The change in $a^{*}$ and $b^{*}$ values of green asparagus was attributed to the degradation of chlorophyll, leading to a decrease in greenness intensity and an increase in yellowness intensity [13].

The degree of color change $(\Delta E)$ increased with storage time in all treatment groups (Figure 2a). However, the color change in melatonin-treated asparagus at all concentrations was significantly lower than that of the control from day 5. After 25 days of storage, the color change in 0.5 MLT, 1.0 MLT, and 2.0 MLT groups relative to that in the control amounted to $41.39,52.52$, and $50.96 \%$, respectively. The appearance of green asparagus after 25 days of storage is shown in Figure $2 \mathrm{~b}$. All the samples showed evidence of wrinkling, mostly in the middle and basal parts. However, the control asparagus showed more wrinkling than melatonin-treated asparagus. Melatonin-treated asparagus (1.0 MLT and 2.0 MLT) had a brighter color than the control asparagus due to less water loss than control, consistent with the total color difference results. 


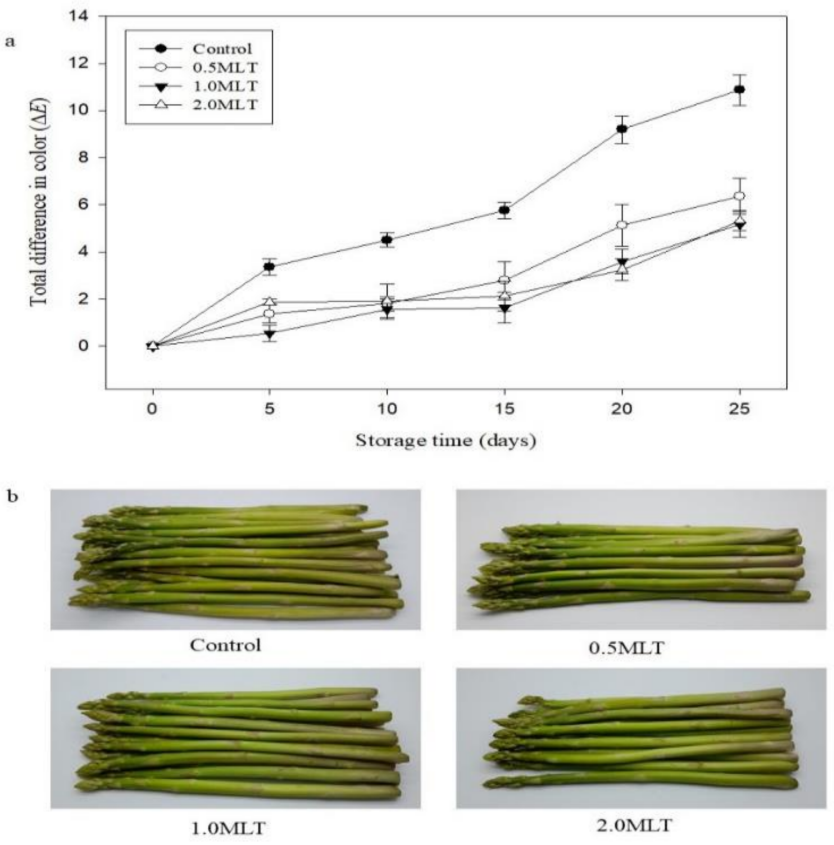

Figure 2. (a) Color change $(\Delta E)$ in green asparagus during 25 days of storage at $4{ }^{\circ} \mathrm{C}$ and $90 \%$ relative humidity. Treatment in melatonin solution: 0.5 MLT $(50 \mu \mathrm{M}), 1.0$ MLT $(100 \mu \mathrm{M}), 2.0$ MLT $(200 \mu \mathrm{M})$; control (distilled water). (b) Appearance of green asparagus after 25 days of storage.

Normally, the chlorophyll content of fresh green asparagus varies widely between 9 and $52 \mathrm{mg} / \mathrm{kg}$ FW $[5,13,42,43]$. The initial chlorophyll concentration depends on several factors, including genetics, environmental conditions, and production methods. However, after harvesting, the chlorophyll content in green asparagus decreases gradually with storage time. Previous studies have shown that the chlorophyll content of green asparagus decreases by $60-66 \%$ when stored at $4{ }^{\circ} \mathrm{C}$ for 30 days [5]. The initial chlorophyll content of asparagus in this study was approximately $25 \mathrm{mg} / \mathrm{Kg} \mathrm{FW}$ (Table 3). It declined gradually during the storage period for both the control and melatonin-treated asparagus. There were no differences between the chlorophyll contents of the control and melatonin-treated asparagus on day 0 . However, the chlorophyll content of melatonin-treated asparagus was significantly higher than that of the control from day 5 until the end of storage. By day 25, 0.5 MLT, 1.0 MLT, and 2.0 MLT showed a 20.93, 40.41 and 33.57\% delay, respectively, in the decrease in chlorophyll content compared with the control. This may be because melatonin functions as an anti-senescence agent, downregulating key chlorophyll catabolism enzymes and other senescence-promoting genes [20]. The decrease in chlorophyll content in green asparagus was consistent with the $\Delta E$ results. Moreover, this finding is in agreement with that of $\mathrm{Wu}$ et al. [22], Miao et al. [44], and Tan et al. [20], who reported a delay in chlorophyll degradation in broccoli florets and Chinese flowering cabbage leaves after melatonin treatment.

Table 3. Effect of melatonin treatment on chlorophyll content $(\mathrm{mg} / \mathrm{Kg}$ fresh weight) of green asparagus during 25 days of storage at $4{ }^{\circ} \mathrm{C}$ and $90 \%$ relative humidity.

\begin{tabular}{ccccccc}
\hline \multirow{2}{*}{ Treatment } & \multicolumn{7}{c}{ Storage Time (Days) } \\
\cline { 2 - 7 } & $\mathbf{0}$ & $\mathbf{5}$ & $\mathbf{1 0}$ & $\mathbf{1 5}$ & $\mathbf{2 0}$ & $\mathbf{2 5}$ \\
\hline Control & $25.75 \pm 0.63^{\mathrm{a}, \mathrm{A}}$ & $20.81 \pm 0.94^{\mathrm{a}, \mathrm{B}}$ & $19.77 \pm 1.05^{\mathrm{a}, \mathrm{BC}}$ & $18.30 \pm 0.96^{\mathrm{a}, \mathrm{CD}}$ & $17.50 \pm 0.49^{\mathrm{a}, \mathrm{D}}$ & $15.07 \pm 0.39^{\mathrm{a}, \mathrm{E}}$ \\
$0.5 \mathrm{MLT}$ & $25.13 \pm 0.46^{\mathrm{a}, \mathrm{A}}$ & $23.55 \pm 1.26^{\mathrm{b}, \mathrm{B}}$ & $22.53 \pm 0.92^{\mathrm{b}, \mathrm{BC}}$ & $21.77 \pm 0.51^{\mathrm{b}, \mathrm{CD}}$ & $20.53 \pm 0.68^{\mathrm{b}, \mathrm{D}}$ & $19.06 \pm 0.53^{\mathrm{b}, \mathrm{E}}$ \\
$1.0 \mathrm{MLT}$ & $25.90 \pm 0.49^{\mathrm{a}, \mathrm{A}}$ & $24.38 \pm 0.26^{\mathrm{b}, \mathrm{B}}$ & $23.20 \pm 0.40^{\mathrm{b}, \mathrm{C}}$ & $22.79 \pm 0.76^{\mathrm{b}, \mathrm{C}}$ & $22.12 \pm 0.67^{\mathrm{c}, \mathrm{CD}}$ & $21.16 \pm 0.73^{\mathrm{d}, \mathrm{E}}$ \\
$2.0 \mathrm{MLT}$ & $25.41^{\mathrm{a}} \pm 0.92^{\mathrm{a}, \mathrm{A}}$ & $24.20 \pm 0.43^{\mathrm{b}, \mathrm{B}}$ & $23.10 \pm 0.46^{\mathrm{b}, \mathrm{BC}}$ & $22.24 \pm 0.54^{\mathrm{b}, \mathrm{C}}$ & $20.48 \pm 0.96^{\mathrm{b}, \mathrm{D}}$ & $20.13 \pm 0.44^{\mathrm{c}, \mathrm{D}}$ \\
\hline
\end{tabular}

Treatment in melatonin solution: 0.5 MLT $(50 \mu \mathrm{M}), 1.0 \mathrm{MLT}(100 \mu \mathrm{M}), 2.0$ MLT $(200 \mu \mathrm{M})$; control (distilled water). Chlorophyll content values $(\mathrm{mg} / \mathrm{kg}$ fresh weight) are presented as mean \pm standard deviation $(n=3)$. Different superscript lowercase letters in the same column indicate significant differences $(p<0.05)$; Different superscript uppercase letters in the same row indicate significant differences $(p<0.05)$. 


\subsection{Effect of Melatonin Treatment on Vitamin C Content}

Vitamin C content can serve as a freshness index of green asparagus because it is known to decrease rapidly with prolonged storage time [45]. The vitamin $C$ content of asparagus was initially in the range of $29.87-30.43 \mathrm{mg} / 100 \mathrm{~g}$ FW (Table 4), decreasing gradually with increasing storage time in both controls and melatonin-treated asparagus. There was no significant difference between vitamin $C$ levels in control and melatonintreated asparagus up to day 10 . However, 100 and $200 \mu \mathrm{M}$ melatonin-treated asparagus had significantly higher vitamin $C$ content than the control at day 15 of storage. At the end of the storage period, the vitamin C content of 0.5 MLT, 1.0 MLT, and 2.0 MLT was $31.21,36.25$, and $37.73 \%$ higher that of the control group, respectively. This result is in agreement with that of Miao et al. [44] and Shekari et al. [46], who reported that melatonin treatment delayed the decrease in vitamin $\mathrm{C}$ content during storage of broccoli florets and mushrooms, respectively.

Table 4. Effect of melatonin treatment on vitamin C content (mg/100 $\mathrm{g}$ fresh weight) of green asparagus during 25 days of storage at $4{ }^{\circ} \mathrm{C}$ and $90 \%$ relative humidity.

\begin{tabular}{ccccccc}
\hline \multirow{2}{*}{ Treatment } & \multicolumn{7}{c}{ Storage Time (Days) } \\
\cline { 2 - 7 } & $\mathbf{0}$ & $\mathbf{5}$ & $\mathbf{1 0}$ & $\mathbf{1 5}$ & $\mathbf{2 0}$ & $\mathbf{2 5}$ \\
\hline Control & $30.20 \pm 1.18^{\mathrm{a}, \mathrm{A}}$ & $29.23 \pm 1.75^{\mathrm{a}, \mathrm{A}}$ & $25.26 \pm 2.12^{\mathrm{a}, \mathrm{B}}$ & $18.38 \pm 1.10^{\mathrm{a}, \mathrm{C}}$ & $16.04 \pm 1.10^{\mathrm{a}, \mathrm{C}}$ & $12.88^{\mathrm{b}} \pm 1.53^{\mathrm{a}, \mathrm{D}}$ \\
0.5 MLT & $29.87 \pm 1.19^{\mathrm{a}, \mathrm{A}}$ & $29.30 \pm 2.86^{\mathrm{a}, \mathrm{AB}}$ & $26.64 \pm 0.63^{\mathrm{a}, \mathrm{B}}$ & $21.22 \pm 2.02^{\mathrm{ab}, \mathrm{C}}$ & $18.49^{\mathrm{a}} \pm 1.56^{\mathrm{b}, \mathrm{CD}}$ & $16.90^{\mathrm{a}} \pm 0.80^{\mathrm{b}, \mathrm{D}}$ \\
1.0 MLT & $30.43 \pm 1.33^{\mathrm{a}, \mathrm{A}}$ & $31.33 \pm 2.60^{\mathrm{a}, \mathrm{A}}$ & $26.78 \pm 0.70^{\mathrm{a}, \mathrm{B}}$ & $22.33 \pm 2.02^{\mathrm{b}, \mathrm{C}}$ & $20.54 \pm 0.80^{\mathrm{b}, \mathrm{C}}$ & $17.55 \pm 1.32^{\mathrm{b}, \mathrm{D}}$ \\
2.0 MLT & $29.92 \pm 0.52^{\mathrm{a}, \mathrm{A}}$ & $30.57 \pm 1.97^{\mathrm{a}, \mathrm{A}}$ & $26.50 \pm 1.19^{\mathrm{a}, \mathrm{B}}$ & $22.58 \pm 0.95^{\mathrm{b}, \mathrm{C}}$ & $20.57 \pm 0.66^{\mathrm{b}, \mathrm{C}}$ & $17.74 \pm 2.20^{\mathrm{b}, \mathrm{D}}$ \\
\hline
\end{tabular}

Treatment in melatonin solution: 0.5 MLT $(50 \mu \mathrm{M}), 1.0 \mathrm{MLT}(100 \mu \mathrm{M}), 2.0$ MLT $(200 \mu \mathrm{M})$; control (distilled water). Vitamin C content values $(\mathrm{mg} / 100 \mathrm{~g}$ fresh weight) are presented as mean \pm standard deviation $(n=3)$. Different superscript lowercase letters in the same column indicate significant differences $(p<0.05)$; Different superscript uppercase letters in the same row indicate significant differences $(p<0.05)$.

\subsection{Effect of Melatonin Treatment on Lignin Content}

Lignin is a complex polymer of phenylpropanoid residues that imparts rigidity and is mainly deposited in the cell walls [4]. In asparagus shoots, lignin is found primarily in the middle and basal parts; the amount is directly related to freshness. Increased lignin content reduces the desirable sensory characteristics and the market value of asparagus [47]. The initial lignin content of all treatment groups was approximately 30-31 g/Kg FW (Table 5), which increased gradually with time. From day 0 to day 25, the lignin content of controls increased by $139.13 \%$ whereas that of 0.5 MLT, 1.0 MLT, and 2.0 MLT increased by 120.00 , 90.58 , and $93.09 \%$, respectively. The lignification results were consistent with the increase in the firmness and rigidity of the basal part (Table 1) and indicate that melatonin treatment significantly delays lignification of green asparagus during cold storage.

Table 5. Effect of melatonin treatment on lignin content ( $\mathrm{g} / \mathrm{Kg}$ fresh weight) of green asparagus during 25 days of storage at $4{ }^{\circ} \mathrm{C}$ and $90 \%$ relative humidity.

\begin{tabular}{ccccccc}
\hline \multirow{2}{*}{ Treatment } & \multicolumn{7}{c}{ Storage Time (Days) } \\
\cline { 2 - 7 } & $\mathbf{0}$ & $\mathbf{5}$ & $\mathbf{1 0}$ & $\mathbf{1 5}$ & $\mathbf{2 0}$ & $\mathbf{2 5}$ \\
\hline Control & $31.33 \pm 3.21^{\mathrm{a}, \mathrm{A}}$ & $40.91 \pm 3.31^{\mathrm{b}, \mathrm{B}}$ & $50.85 \pm 1.44^{\mathrm{c}, \mathrm{C}}$ & $58.58 \pm 1.08^{\mathrm{c}, \mathrm{D}}$ & $69.35 \pm 1.08^{\mathrm{c}, \mathrm{E}}$ & $74.92 \pm 2.97^{\mathrm{c}, \mathrm{F}}$ \\
$0.5 \mathrm{MLT}$ & $30.71 \pm 2.16^{\mathrm{a}, \mathrm{A}}$ & $36.17 \pm 3.15^{\mathrm{ab}, \mathrm{B}}$ & $42.97 \pm 3.06^{\mathrm{b}, \mathrm{C}}$ & $51.94 \pm 2.11^{\mathrm{b}, \mathrm{D}}$ & $59.20 \pm 1.44^{\mathrm{b}, \mathrm{E}}$ & $67.57 \pm 2.97^{\mathrm{b}, \mathrm{F}}$ \\
$1.0 \mathrm{MLT}$ & $31.23 \pm 3.88^{\mathrm{a}, \mathrm{A}}$ & $34.07 \pm 1.26^{\mathrm{a}, \mathrm{A}}$ & $38.69 \pm 0.74^{\mathrm{a}, \mathrm{B}}$ & $42.51 \pm 1.15^{\mathrm{a}, \mathrm{BC}}$ & $45.46 \pm 2.54^{\mathrm{a}, \mathrm{C}}$ & $59.52 \pm 1.68^{\mathrm{a}, \mathrm{D}}$ \\
$2.0 \mathrm{MLT}$ & $30.86 \pm 4.90^{\mathrm{a}, \mathrm{A}}$ & $34.20 \pm 2.05^{\mathrm{a}, \mathrm{AB}}$ & $38.33^{\mathrm{a}} \pm 1.65^{\mathrm{a}, \mathrm{BC}}$ & $42.33 \pm 1.23^{\mathrm{a}, \mathrm{CD}}$ & $45.54 \pm 3.45^{\mathrm{a}, \mathrm{D}}$ & $59.59 \pm 3.47^{\mathrm{a}, \mathrm{E}}$ \\
\hline
\end{tabular}

Treatment in melatonin solution: 0.5 MLT $(50 \mu \mathrm{M}), 1.0 \mathrm{MLT}(100 \mu \mathrm{M}), 2.0 \mathrm{MLT}(200 \mu \mathrm{M})$; control (distilled water). Lignin content values $(\mathrm{g} / 100 \mathrm{mg}$ fresh weight) are presented as mean \pm standard deviation $(n=3)$. Different superscript lowercase letters in the same column indicate significant differences $(p<0.05)$; Different superscript uppercase letters in the same row indicate significant differences $(p<0.05)$. 


\subsection{Effect of Melatonin Treatment on $\mathrm{H}_{2} \mathrm{O}_{2}$ Content}

$\mathrm{H}_{2} \mathrm{O}_{2}$ is a reactive oxygen species (ROS) with the potential to induce cell membrane damage, which leads to the senescence of fruits and vegetables [38]. The initial $\mathrm{H}_{2} \mathrm{O}_{2}$ content of the controls was $9.03 \pm 1.65 \mathrm{mg} / 100 \mathrm{~g} \mathrm{FW}$, whereas that of melatonin-treated asparagus was approximately $8.13-8.73 \mathrm{mg} / 100 \mathrm{~g}$ FW (Table 6). The $\mathrm{H}_{2} \mathrm{O}_{2}$ concentration increased gradually in all the treatment groups during storage. However, melatonin-treated asparagus had significantly lower $\mathrm{H}_{2} \mathrm{O}_{2}$ content than the controls from day 5 to day 25 . Higher melatonin concentration was associated with lower $\mathrm{H}_{2} \mathrm{O}_{2}$ content at day 15 of storage. Nevertheless, there was no significant difference between the $\mathrm{H}_{2} \mathrm{O}_{2}$ content of 1.0 MLT and 2.0 MLT at any time point during storage, thus indicating that melatonin treatment reduces the rate of generation of $\mathrm{H}_{2} \mathrm{O}_{2}$. According to Lwin et al. [6], $\mathrm{H}_{2} \mathrm{O}_{2}$ is involved in chlorophyll bleaching when catalyzed by POD at the proper concentration of phenols. Therefore, a lower $\mathrm{H}_{2} \mathrm{O}_{2}$ content reduces chlorophyll degradation and delays quality deterioration. This finding is supported by the color change and chlorophyll degradation assay results (Tables 2 and 3, respectively).

Table 6. Effect of melatonin treatment on hydrogen peroxide content ( $\mathrm{mg} / 100 \mathrm{~g}$ fresh weight) of green asparagus during 25 days of storage at $4{ }^{\circ} \mathrm{C}$ and $90 \%$ relative humidity.

\begin{tabular}{ccccccc}
\hline \multirow{2}{*}{ Treatment } & \multicolumn{7}{c}{ Storage Time (Days) } \\
\cline { 2 - 7 } & $\mathbf{0}$ & $\mathbf{5}$ & $\mathbf{1 0}$ & $\mathbf{1 5}$ & $\mathbf{2 0}$ & $\mathbf{2 5}$ \\
\hline Control & $9.03 \pm 1.65^{\mathrm{a}, \mathrm{A}}$ & $13.33 \pm 0.67^{\mathrm{b}, \mathrm{B}}$ & $15.33 \pm 1.00^{\mathrm{c}, \mathrm{C}}$ & $16.63 \pm 1.30^{\mathrm{c}, \mathrm{C}}$ & $19.33 \pm 0.68^{\mathrm{c}, \mathrm{D}}$ & $22.43 \pm 0.59^{\mathrm{c}, \mathrm{D}}$ \\
$0.5 \mathrm{MLT}$ & $8.13 \pm 0.67^{\mathrm{a}, \mathrm{A}}$ & $9.90 \pm 0.19^{\mathrm{a}, \mathrm{AB}}$ & $11.60 \pm 0.67^{\mathrm{b}, \mathrm{BC}}$ & $12.70 \pm 1.67^{\mathrm{b}, \mathrm{C}}$ & $15.28 \pm 0.95^{\mathrm{b}, \mathrm{D}}$ & $17.33 \pm 0.80^{\mathrm{b}, \mathrm{D}}$ \\
$1.0 \mathrm{MLT}$ & $8.23 \pm 1.06^{\mathrm{a}, \mathrm{A}}$ & $8.93 \pm 0.81^{\mathrm{a}, \mathrm{AB}}$ & $9.57 \pm 0.7^{\mathrm{ab}, \mathrm{ABC}}$ & $10.07 \pm 0.99^{\mathrm{a}, \mathrm{BC}}$ & $11.07 \pm 0.59^{\mathrm{a}, \mathrm{C}}$ & $14.20 \pm 0.70^{\mathrm{a}, \mathrm{C}}$ \\
$2.0 \mathrm{MLT}$ & $8.73 \pm 0.67^{\mathrm{a}, \mathrm{A}}$ & $8.48 \pm 1.20^{\mathrm{a}, \mathrm{A}}$ & $9.00 \pm 0.70^{\mathrm{a}, \mathrm{A}}$ & $10.47 \pm 0.31^{\mathrm{a}, \mathrm{AB}}$ & $12.17 \pm 1.88^{\mathrm{a}, \mathrm{B}}$ & $14.57^{2} \pm 0.55^{\mathrm{a}, \mathrm{B}}$ \\
\hline
\end{tabular}

Treatment in melatonin solution: 0.5 MLT (50 $\mu \mathrm{M}), 1.0 \mathrm{MLT}(100 \mu \mathrm{M}), 2.0 \mathrm{MLT}(200 \mu \mathrm{M})$; control (distilled water). Hydrogen peroxide content values $(\mathrm{mg} / 100 \mathrm{mg}$ fresh weight) values are presented as mean \pm standard deviation $(n=3)$. Different superscript lowercase letters in the same column indicate significant differences $(p<0.05)$; Different superscript uppercase letters in the same row indicate significant differences $(p<0.05)$.

\subsection{Effect of Melatonin Treatment on Enzymatic Activity}

Lignification is a fundamental developmental process in higher plants and is controlled by several enzymes including PAL, cinnamate 4-hydroxylase, and 4-coumarate-CoA ligase [48]. PAL is the key enzyme involved in the phenylpropanoid and lignin synthesis pathways. A decrease in the overall quality and shelf life of asparagus has been correlated with increased PAL activity [31]. Therefore, understanding PAL activity may help predict the shelf life of asparagus after melatonin treatment. PAL activity (Figure 3a) of the control and 0.5 MLT increased and reached the maximum levels of $99.34 \pm 3.12$ and $88.78 \pm 3.30 \mathrm{U} / \mathrm{mg}$ protein, respectively, by day 15 , and then gradually decreased to $62.47 \pm 2.48$ and $62.66 \pm 3.88 \mathrm{U} / \mathrm{mg}$ protein, respectively, at day 25 . Conversely, the PAL activity of 1.0 MLT and 2.0 MLT was significantly lower than that of the control at day 15 by 32.55 and $31.54 \%$, respectively; by day 25 , it was 14.53 and $11.76 \%$ lower than the control PAL activity, respectively. This finding is consistent with that of the study by Li et al. [7], who reported that melatonin treatment delayed post-harvest lignification of bamboo shoots. Moreover, many studies have reported that inhibition of PAL enzyme activity by post-harvest treatments, such as L-arginine [4], ozone [31], and ammonium sulfate [49] delayed lignin accumulation in asparagus. 

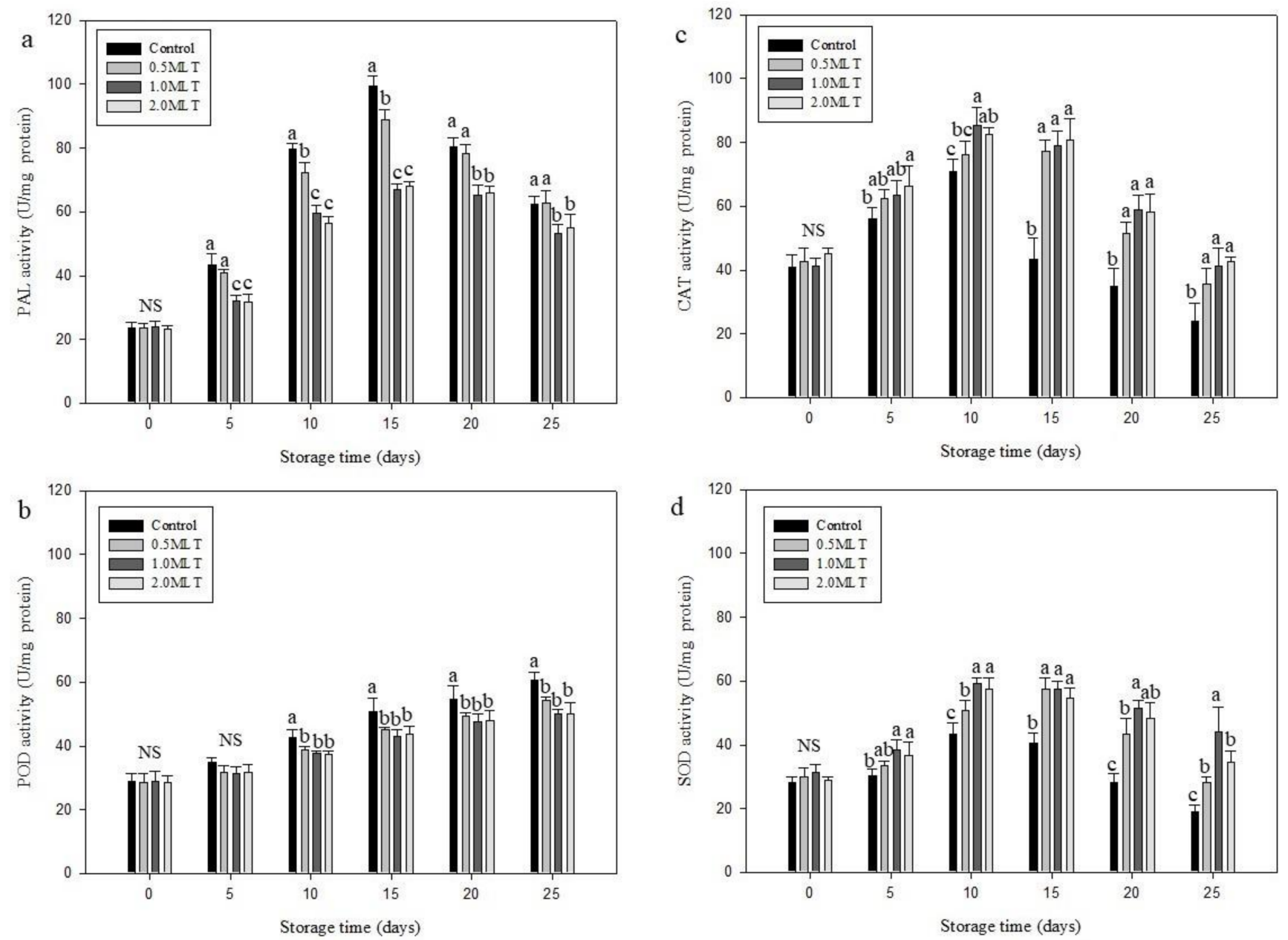

Figure 3. Effect of melatonin treatment on (a) phenylalanine ammonia-lyase (PAL) activity, (b) peroxidase (POD) activity, (c) catalase (CAT) activity, and (d) superoxide dismutase (SOD) activity of green asparagus during 25 days of storage at $4{ }^{\circ} \mathrm{C}$ and $90 \%$ relative humidity. Treatment in melatonin solution: $0.5 \mathrm{MLT}(50 \mu \mathrm{M}), 1.0 \mathrm{MLT}(100 \mu \mathrm{M}), 2.0 \mathrm{MLT}(200 \mu \mathrm{M})$; control (distilled water). Values are presented as mean \pm standard deviation $(n=3)$. Different letters indicate significant differences $(p<0.05)$; NS = not significant.

POD activity correlates with the degree of lignification in asparagus, as this enzyme promotes the interlinking of lignin precursors following $\mathrm{H}_{2} \mathrm{O}_{2}$ decomposition [29]. POD activity in the asparagus was initially in the range of $28.56-28.99 \mathrm{U} / \mathrm{mg}$ protein (Figure $3 \mathrm{~b}$ ). The enzyme activity increased steadily in both controls and melatonin-treated asparagus. However, POD activity was lower in all melatonin-treated asparagus groups than in the control at day 10 of storage. At day 25, the POD activity of 0.5 MLT, 1.0 MLT, and 2.0 MLT was lower than that of the control by $10.41,17.61$, and $17.17 \%$, respectively. These results indicate that melatonin treatment delays lignification in asparagus through the regulation of PAL and POD activity.

There were similar changes in CAT activity of both control and melatonin-treated asparagus (Figure 3c)-i.e., an increase over the first 10 days, followed by a decrease with prolonged storage time. However, CAT activity of all melatonin treatment groups was higher than that of the control at every sampling day; the highest CAT activity $(85.33 \pm 5.51 \mathrm{U} / \mathrm{mg}$ protein) was observed in 1.0 MLT at day 10 of storage. CAT activity of the control decreased sharply from day 10 to day 15 by $39.4 \%$, whereas that of all melatonin treatment groups was nearly the same at day 15 as that at day 10 . This observation indicates that melatonin treatment activates CAT at the beginning stage and delays the loss of CAT activity at the later stages. 
The change in SOD activity of control and melatonin-treated asparagus (Figure 3d) showed the same trend as the change in CAT activity (Figure 3c). Initially, there was no significant difference between the control and melatonin-treated groups. Thereafter, the SOD activity of the melatonin treatment groups was consistently higher than that of the control group. The highest SOD activity in the control group $(43.33 \pm 3.51 \mathrm{U} / \mathrm{mg}$ protein) was observed at day 10, whereas the highest SOD activity in 0.5 MLT, 1.0 MLT, and 2.0 MLT was observed at day 15, 10, and 10, respectively (i.e., $57.33 \pm 3.51,59.33 \pm 1.53$, and $58.67 \pm 3.06 \mathrm{U} / \mathrm{mg}$ protein, respectively). At day 25 , SOD activity in $0.5 \mathrm{MLT}, 1.0 \mathrm{MLT}$, and 2.0 MLT were higher than that of the control group by $49.10,131.57$, and $82.47 \%$, respectively. This result indicates that melatonin treatment promotes SOD activity.

ROS promote senescence of fruits and vegetables because they destroy biological macromolecules and affect metabolism, resulting in damages such as increasing cell membrane leakage [38,50]. However, $\mathrm{ROS}$ such as $\mathrm{H}_{2} \mathrm{O}_{2}$ and singlet oxygen can be eliminated by CAT and SOD, which protect against free radical attack $[29,51]$. Therefore, increasing CAT and SOD activity delays post-harvest deterioration of fruits and vegetables. According to the data obtained from the $\mathrm{H}_{2} \mathrm{O}_{2}$ content, CAT activity, and POD activity assays, we suggest that melatonin treatment activates CAT and POD, thereby reducing $\mathrm{H}_{2} \mathrm{O}_{2}$ content and delaying green asparagus deterioration. This result is consistent with that of studies that noted increased CAT and POD activity after melatonin treatment of bamboo shoots, pomegranates, and tomatoes $[7,52,53]$.

\section{Conclusions}

The findings of the present study revealed that melatonin treatment effectively retarded the deterioration of green asparagus quality attributes during a cold-storage period of 25 days, as indicated by a decrease in the percentage weight loss and $\mathrm{Ri}$, as well as a delay in chlorophyll degradation. Melatonin treatment also reduced lignin content, which led to a delay in the increase in firmness via the regulation of PAL and POD activity. Moreover, melatonin treatment increased CAT and POD enzyme activity, leading to reduced $\mathrm{H}_{2} \mathrm{O}_{2}$ content and extended shelf life. We recommend treatment with $100 \mu \mathrm{M}$ melatonin solution as a practical method to prolong the shelf life of green asparagus. However, melatonin is prone to degradation; therefore, there is a need to develop specialized materials such as nanoporous materials for protecting melatonin from light and air.

Author Contributions: Conceptualization, A.B. and Y.S.L.; methodology, A.B.; validation, A.B. and Y.S.L.; formal analysis, A.B., M.L., M.K., and P.I.; investigation, A.B. and P.I.; data curation, A.B.; writing—original draft preparation, A.B.; writing—review and editing, Y.S.L.; supervision, Y.S.L. All authors have read and agreed to the published version of the manuscript.

Funding: This research was funded by the Korea Institute of Planning and Evaluation for Technology in Food, Agriculture, Forestry, and Fisheries (IPET) through the Agricultural Export Business Model Development Program, funded by the Ministry of Agriculture, Food, and Rural Affairs (MAFRA; 319091-03).

Data Availability Statement: The data supporting the findings of this study are included in this article.

Conflicts of Interest: The authors declare no conflict of interest.

\section{References}

1. Noperi-Mosqueda, L.C.; López-Moreno, F.J.; Navarro-León, E.; Sánchez, E.; Blasco, B.; A Moreno, D.; Soriano, T.; Ruiz, J.M. Effects of asparagus decline on nutrients and phenolic compounds, spear quality, and allelopathy. Sci. Hortic. 2019, $261,109029$. [CrossRef]

2. Chen, H.; Lu, Z.; Wang, J.; Chen, T.; Gao, J.; Zheng, J.; Zhang, S.; Xi, J.; Huang, X.; Guo, A.; et al. Induction of new tetraploid genotypes and heat tolerance assessment in Asparagus officinalis L. Sci. Hortic. 2020, 264, 109168. [CrossRef]

3. Tzoumaki, M.V.; Biliaderis, C.G.; Vasilakakis, M. Impact of edible coatings and packaging on quality of white asparagus (Asparagus officinalis, L.) during cold storage. Food Chem. 2009, 117, 55-63. [CrossRef]

4. Wang, X.; Gu, S.; Chen, B.; Huang, J.; Xing, J. Effect of postharvest l-arginine or cholesterol treatment on the quality of green asparagus (Asparagus officinalis L.) spears during low temperature storage. Sci. Hortic. 2017, 225, 788-794. [CrossRef] 
5. Li, T.; Zhang, M. Effects of modified atmosphere package (MAP) with a silicon gum film window on the quality of stored green asparagus (Asparagus officinalis L) spears. LWT 2015, 60, 1046-1053. [CrossRef]

6. Lwin, W.W.; Srilaong, V.; Boonyaritthongchai, P.; Wongs-Aree, C.; Pongprasert, N. Electrostatic atomised water particles reduces postharvest lignification and maintain asparagus quality. Sci. Hortic. 2020, 271, 109487. [CrossRef]

7. Li, C.; Suo, J.; Xuan, L.; Ding, M.; Zhang, H.; Song, L.; Ying, Y. Bamboo shoot-lignification delay by melatonin during low temperature storage. Postharvest Biol. Technol. 2019, 156, 110933. [CrossRef]

8. Stoffyn, O.M.; Tsao, R.; Liu, R.; Wolyn, D.J. The effects of environment and storage on rutin concentration in two asparagus cultivars grown in southern Ontario. Can. J. Plant Sci. 2012, 92, 901-912. [CrossRef]

9. Drinkwater, J.M.; Tsao, R.; Liu, R.; Wolyn, D.J. Genetic variation and heritability of rutin and glutathione concentrations in asparagus spears. Can. J. Plant Sci. 2014, 94, 1355-1362. [CrossRef]

10. Papoulias, E.; Siomos, A.S.; Koukounaras, A.; Gerasopoulos, D.; Kazakis, E. Effects of Genetic, Pre- and Post-Harvest Factors on Phenolic Content and Antioxidant Capacity of White Asparagus Spears. Int. J. Mol. Sci. 2009, 10, 5370-5380. [CrossRef]

11. Toscano, S.; Rizzo, V.; Licciardello, F.; Romano, D.; Muratore, G. Packaging Solutions to Extend the Shelf Life of Green Asparagus (Asparagus officinalis L.) 'Vegalim'. Foods 2021, 10, 478. [CrossRef] [PubMed]

12. Huyskens-Keil, S.; Herppich, W. High CO2 effects on postharvest biochemical and textural properties of white asparagus (Asparagus officinalis L.) spears. Postharvest Biol. Technol. 2013, 75, 45-53. [CrossRef]

13. Qiu, M.; Wu, C.; Ren, G.; Liang, X.; Wang, X.; Huang, J. Effect of chitosan and its derivatives as antifungal and preservative agents on postharvest green asparagus. Food Chem. 2014, 155, 105-111. [CrossRef] [PubMed]

14. Albanese, D.; Russo, L.; Cinquanta, L.; Brasiello, A.; Di Matteo, M. Physical and chemical changes in minimally processed green asparagus during cold-storage. Food Chem. 2007, 101, 274-280. [CrossRef]

15. Siomos, A.; Sfakiotakis, E.M.; Dogras, C.C. Modified atmosphere packaging of white asparagus spears: Composition, color and textural quality responses to temperature and light. Sci. Hortic. 2000, 84, 1-13. [CrossRef]

16. Gao, H.; Lu, Z.; Yang, Y.; Wang, D.; Yang, T.; Cao, M.; Cao, W. Melatonin treatment reduces chilling injury in peach fruit through its regulation of membrane fatty acid contents and phenolic metabolism. Food Chem. 2018, 245, 659-666. [CrossRef] [PubMed]

17. Sun, Q.; Zhang, N.; Wang, J.; Cao, Y.; Li, X.; Zhang, H.; Zhang, L.; Tan, D.-X.; Guo, Y.-D. A label-free differential proteomics analysis reveals the effect of melatonin on promoting fruit ripening and anthocyanin accumulation upon postharvest in tomato. $J$. Pineal Res. 2016, 61, 138-153. [CrossRef]

18. Liu, C.; Zheng, H.; Sheng, K.; Liu, W.; Zheng, L. Effects of melatonin treatment on the postharvest quality of strawberry fruit. Postharvest Biol. Technol. 2018, 139, 47-55. [CrossRef]

19. Ma, Q.; Zhang, T.; Zhang, P.; Wang, Z.-Y. Melatonin attenuates postharvest physiological deterioration of cassava storage roots. J. Pineal Res. 2016, 60, 424-434. [CrossRef]

20. Tan, X.-L.; Zhao, Y.-T.; Shan, W.; Kuang, J.-F.; Lu, W.-J.; Su, X.-G.; Tao, N.-G.; Lakshmanan, P.; Chen, J.-Y. Melatonin delays leaf senescence of postharvest Chinese flowering cabbage through ROS homeostasis. Food Res. Int. 2020, 138, 109790. [CrossRef]

21. Kong, X.-M.; Ge, W.-Y.; Wei, B.-D.; Zhou, Q.; Zhou, X.; Zhao, Y.-B.; Ji, S.-J. Melatonin ameliorates chilling injury in green bell peppers during storage by regulating membrane lipid metabolism and antioxidant capacity. Postharvest Biol. Technol. 2020, 170, 111315. [CrossRef]

22. Wu, C.; Cao, S.; Xie, K.; Chi, Z.; Wang, J.; Wang, H.; Wei, Y.; Shao, X.; Zhang, C.; Xu, F.; et al. Melatonin delays yellowing of broccoli during storage by regulating chlorophyll catabolism and maintaining chloroplast ultrastructure. Postharvest Biol. Technol. 2020, 172, 111378. [CrossRef]

23. Castelló, M.L.; Fito, P.J.; Chiralt, A. Changes in respiration rate and physical properties of strawberries due to osmotic dehydration and storage. J. Food Eng. 2010, 97, 64-71. [CrossRef]

24. AOAC. Official Methods of Analysis: Changes in Official Methods of Analysis Made at the Annual Meeting; AOAC: Washington, DC, USA, 1975.

25. Fukushima, R.S.; Hatfield, R.D. Extraction and Isolation of Lignin for Utilization as a Standard to Determine Lignin Concentration Using the Acetyl Bromide Spectrophotometric Method. J. Agric. Food Chem. 2001, 49, 3133-3139. [CrossRef] [PubMed]

26. Jana, S.; Choudhuri, M.A. Glycolate metabolism of three submersed aquatic angiosperms during ageing. Aquat. Bot. 1982, 12, 345-354. [CrossRef]

27. Wang, Y.; Chen, J.-Y.; Jiang, Y.-M.; Lu, W.-J. Cloning and expression analysis of phenylalanine ammonia-lyase in relation to chilling tolerance in harvested banana fruit. Postharvest Biol. Technol. 2007, 44, 34-41. [CrossRef]

28. Zhang, Z.; Pang, X.; Xuewu, D.; Ji, Z.; Jiang, Y. Role of peroxidase in anthocyanin degradation in litchi fruit pericarp. Food Chem. 2005, 90, 47-52. [CrossRef]

29. Li, W.; Zhang, M.; Wang, S. Effect of three-stage hypobaric storage on membrane lipid peroxidation and activities of defense enzyme in green asparagus. LWT 2008, 41, 2175-2181. [CrossRef]

30. Tang, H.; Hu, Y.-Y.; Yu, W.-W.; Song, L.-L.; Wu, J.-S. Growth, photosynthetic and physiological responses of Torreya grandis seedlings to varied light environments. Trees 2015, 29, 1011-1022. [CrossRef]

31. An, J.; Zhang, M.; Lu, Q. Changes in some quality indexes in fresh-cut green asparagus pretreated with aqueous ozone and subsequent modified atmosphere packaging. J. Food Eng. 2007, 78, 340-344. [CrossRef]

32. Saltveit, M.E. Respiratory Metabolism. In Postharvest Physiology and Biochemistry of Fruits and Vegetables; Elsevier: Amsterdam, The Netherlands, 2019; pp. 73-91. 
33. Tan, X.-L.; Fan, Z.-Q.; Zeng, Z.-X.; Shan, W.; Kuang, J.-F.; Lu, W.-J.; Su, X.-G.; Tao, N.-G.; Lakshmanan, P.; Chen, J.-Y.; et al. Exogenous melatonin maintains leaf quality of postharvest Chinese flowering cabbage by modulating respiratory metabolism and energy status. Postharvest Biol. Technol. 2021, 177, 111524. [CrossRef]

34. Peretó, J. Embden-Meyerhof-Parnas Pathway. In Encyclopedia of Astrobiology; Springer: Berlin/Heidelberg, Germany, $2011 ;$ p. 485.

35. Onik, J.C.; Wai, S.C.; Li, A.; Lin, Q.; Sun, Q.; Wang, Z.; Duan, Y. Melatonin treatment reduces ethylene production and maintains fruit quality in apple during postharvest storage. Food Chem. 2020, 337, 127753. [CrossRef] [PubMed]

36. Miranda, S.; Vilches, P.; Suazo, M.; Pavez, L.; García, K.; Méndez, M.A.; González, M.; Meisel, L.A.; Defilippi, B.G.; del Pozo, T. Melatonin triggers metabolic and gene expression changes leading to improved quality traits of two sweet cherry cultivars during cold storage. Food Chem. 2020, 319, 126360. [CrossRef]

37. Li, L.; Kitazawa, H.; Zhang, X.; Zhang, L.; Sun, Y.; Wang, X.; Liu, Z.; Guo, Y.; Yu, S. Melatonin retards senescence via regulation of the electron leakage of postharvest white mushroom (Agaricus bisporus). Food Chem. 2020, 340, 127833. [CrossRef]

38. Xu, T.; Chen, Y.; Kang, H. Melatonin Is a Potential Target for Improving Post-Harvest Preservation of Fruits and Vegetables. Front. Plant Sci. 2019, 10, 1388. [CrossRef]

39. Hu, W.; Yang, H.; Tie, W.; Yan, Y.; Ding, Z.; Liu, Y.; Wu, C.; Wang, J.; Reiter, R.J.; Tan, D.-X.; et al. Natural Variation in Banana Varieties Highlights the Role of Melatonin in Postharvest Ripening and Quality. J. Agric. Food Chem. 2017, 65, 9987-9994. [CrossRef]

40. Pandey, S.; A Ranade, S.; Nagar, P.K.; Kumar, N. Role of polyamines and ethylene as modulators of plant senescence. J. Biosci. 2000, 25, 291-299. [CrossRef] [PubMed]

41. Ella, L.; Zion, A.; Nehemia, A.; Amnon, L. Effect of the ethylene action inhibitor 1-methylcyclopropene on parsley leaf senescence and ethylene biosynthesis. Postharvest Biol. Technol. 2003, 30, 67-74. [CrossRef]

42. Hörtensteiner, S. Chlorophyll degradation during senescence. Annu. Rev. Plant Biol. 2006, 57, 55-77. [CrossRef]

43. An, J.; Zhang, M.; Lu, Q.; Zhang, Z. Effect of a prestorage treatment with 6-benzylaminopurine and modified atmosphere packaging storage on the respiration and quality of green asparagus spears. J. Food Eng. 2006, 77, 951-957. [CrossRef]

44. Miao, H.; Zeng, W.; Zhao, M.; Wang, J.; Wang, Q. Effect of melatonin treatment on visual quality and health-promoting properties of broccoli florets under room temperature. Food Chem. 2020, 319, 126498. [CrossRef]

45. Wang, J.; Fan, L. Effect of ultrasound treatment on microbial inhibition and quality maintenance of green asparagus during cold storage. Ultrason. Sonochemistry 2019, 58, 104631. [CrossRef] [PubMed]

46. Shekari, A.; Hassani, R.N.; Aghdam, M.S.; Rezaee, M.; Jannatizadeh, A. The effects of melatonin treatment on cap browning and biochemical attributes of Agaricus bisporus during low temperature storage. Food Chem. 2021, 348, 129074. [CrossRef] [PubMed]

47. Liu, Z.-Y.; Jiang, W.-B. Lignin Deposition and Effect of Postharvest Treatment on Lignification of Green Asparagus (Asparagus officinalis L.). Plant Growth Regul. 2006, 48, 187-193. [CrossRef]

48. Halpin, C. Investigating and Manipulating Lignin Biosynthesis in the Postgenomic Era. In Advances in Botanical Research; Elsevier: Cham, Switzerland, 2004; pp. 63-106. [CrossRef]

49. Toscano, S.; Ferrante, A.; Leonardi, C.; Romano, D. PAL activities in asparagus spears during storage after ammonium sulfate treatments. Postharvest Biol. Technol. 2018, 140, 34-41. [CrossRef]

50. Wang, S.-Y.; Shi, X.-C.; Wang, R.; Wang, H.-L.; Liu, F.; Laborda, P. Melatonin in fruit production and postharvest preservation: A review. Food Chem. 2020, 320, 126642. [CrossRef]

51. Ighodaro, O.; Akinloye, O. First line defence antioxidants-superoxide dismutase (SOD), catalase (CAT) and glutathione peroxidase (GPX): Their fundamental role in the entire antioxidant defence grid. Alex. J. Med. 2018, 54, 287-293. [CrossRef]

52. Ding, F.; Liu, B.; Zhang, S. Exogenous melatonin ameliorates cold-induced damage in tomato plants. Sci. Hortic. 2017, 219, 264-271. [CrossRef]

53. Jannatizadeh, A. Exogenous melatonin applying confers chilling tolerance in pomegranate fruit during cold storage. Sci. Hortic. 2018, 246, 544-549. [CrossRef] 